\title{
Modern Tools and Techniques for Diagnosis and Prognosis of Salt Affected Soils and Poor- Quality Waters
}

\author{
AK Mandal* \\ ICAR-Central Soil Salinity Research Institute (CSSRI), India
}

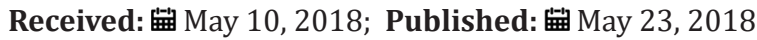

*Corresponding author: AK Mandal, ICAR-Central Soil Salinity Research Institute (CSSRI), India

\section{Introduction}

Soil salinity and brackish ground water are primary concerns for reduced productivity in the arid and semiarid regions of the World covering 953 million ha of land [1]. In India, it occupied 2\% of the TGA and is distributed in fifteen states that covered Genetic plain, central arid and semiarid regions, southern peninsular plain and coastal areas [2]. Transportation and deposition of salts at the lower topographic zones are primary processes controlling genesis and distribution of salty soils in the Genetic plain besides high evaporation in arid zone, salty parent materials and brackish ground use in peninsular plain and inundation of saline sea water in coastal areas are other soil salinization processes [3]. Factors of anthropogenic origin include the use of salty ground water and canal water for irrigation in poorly drained soils of arid and semiarid regions that caused the emergences of water logging, salinization and losses of soil/crop productivity $[4,5]$.

Traditional methods of soil survey using aerial photographs and soil profile studies require enough time and manpower for soil characterization which is limited to small areas. Temporal dynamics of salts is also an important issue which is usually unaddressed in soil survey studies. Indian Remote Sensing Technology (Resources at I\&II) with improved spatial and spectral resolutions have facilitated the diagnosis of salt affected soils in less time and cost effective manner with limited resources. For delineation and characterization of salt affected soils on a reconnaissance scale, a methodology was developed integrating remote sensing data with ground truth and soil studies [6]. Legends were developed to address nature, characteristics and extent of saline and sodic soils for land reclamation \& management. Prognostic studies on soil salinity were also conducted using high resolution remote sensing data (SPOT, MODIS etc.) in Western Yamuna, Bhakra and Sir hind (Haryana and Punjab states); IGNP (Rajasthan state), Sharda Sahayak (Uttar Pradesh state), Ukiah Kakarpar (Gujarat state), Upper Krishna (Karnataka state) and Gandak (Bihar state) canal command areas of India to quantify soil salinization processes integrating topography, soil texture, hydrology and sub-surface soil and aquifer characteristics Spatial variability of salts was studied at farm scale in the Shivari (at Lucknow, Uttar Pradesh state) and Nain (at Panipat, Haryana state) experimental farms of ICAR-CSSRI, representing sodic soils of the Middle- and saline soil and salty groundwater in the Trans-Gang tic plains of India $[7,8]$.

Interpretation of IRS data facilitated the identification strongly salt affected soils by the white to yellowish white tones and high spectral contrast of salt crusts from barren surfaces. Based on the dark blue/black to grey tones in the infrared range (SWIR), the waterlogged soils were clearly identified in canal irrigated areas showing stagnated water at soil surface with poor natural drainage. High reflectance from dry salts during June and freshly precipitated moist salts during March and October enabled the detection of sodic soils and areas with sodic (with high RSC, Residual Sodium Carbonate, and SAR, Sodium Adsorption Ratio) ground water [9]. Contrarily sodic soils with normal ground water showed mixed red and spotted while signatures and high NDVI values for crops with good vegetative covers. Moderately and slightly sodic soils showed mixed spectral signatures for salt crusts, moderate cropping density and surface wetness and is authenticated by ground truth study. The dark red tones of healthy vegetation and high NDVI values are found for normal cropped areas. Differential absorption from seasonal water logging and surface ponding were established in the infrared regions (SWIR) with higher accuracy [8]. Combination of red and infra red bands helped in segregating saline and sodic soils located in different geographic regions (Singh and Mandal 2007). Integration of thermal band interpretation helped in segregating salty areas and sand dunes [10].

Sodic soil profiles indicated prominent natric horizon with clay illuviation, iron and manganese mottles with higher moisture content and calcareous materials at sub-surface depths. Soils showing high PHS, ESP and SAR values and the dominance of carbonate and bicarbonates of sodium in the saturation extract 
indicated sodic nature [11]. High moisture content in soil profiles, salt accumulation at the root zone and salt dynamics in wet and dry cycles are common features of waterlogged (surface ponding), high water table depth (potential water logging) and seasonal water logging in the canal irrigated areas respectively [12]. Continuous use of salty ground water for irrigation in arid and semiarid regions caused salt enrichment in soil profiles. Periodic inundations of saline sea water in coastal fringes, and the use of salty water for fisheries development projects have abandoned large areas of good agricultural lands out of cultivation. Water samples with high $\mathrm{pH}$ and SAR values and at places high RC are typical qualities of water in arid and semiarid regions [13]. Water logging, high clay contents, smectite clay minerals and poor to very poor (sporadic) cropping density and ground water quality are some of the constraints in the peninsular plain, causing difficulty in the detection and delineation of salt affected soils [5]. Black soils of Peninsular (F) region were classified as sodic, as soil ESP (Exchangeable Sodium Percent $>5$ ) is becomes critical at this stage. For management purposes, the complex saline-sodic soils of A (alluvial), B(aeofluvial/arid) and $\mathrm{H}$ (others) are classed as sodic. Due to high salt enrichment in soil profiles, typical soils in coastal (D), deltaic(C) and mud flats mangrove swamps (G) were classified as saline. Benchmark salt affected soils were also identified to support monitoring and management of salt affected soils [14] distributed in fifteen agroclimatic and seven physiographic regions in India (CSSRI 20022005). Interactive databases with climate and geology revealed largest areas (67\%) in the 300-1000 mm rainfall, followed by $75 \%$ in the strong hypothermic (25-27.5oC) temperature zones and 39\% in the Pleistocene and recent geological formations [15]. Recent IRS data [16] revealed distribution of salt affected soils (315617 ha) in 18 districts of Haryana state that showed an increase in areas under saline soils to 145054 ha and decrease of sodic soils to $170563 \mathrm{ha}$, apparently due to soil salinization in irrigated areas and sodic land reclamations (CSSRI 2017-18). Attempts were also taken to update sodic soil database in Uttar Pradesh and areas of saline soils in Gujarat state [17-21].

\section{References}

1. Szabolcs I (1989) Salt Affected Soils. CRC Press, New York, USA, pp: 274.

2. Mandal AK, Sharma RC, Singh Gurbachan, Dagar JC (2010) Computerized database on salt affected soils in India. CSSRI/Technical Bull pp-28.

3. Bhargava GP, Bhattacharjee JC (1982) Morphology genesis and classification of Salt Affected soils. In Review of Soil Research in India $12^{\text {th }}$ International Congress of Soil Science pp: 508-528.

4. Singh G (2009) Salinity related desertification and management strategies: Indian Experience. Land degradation \& Development 20: 367-385.

5. Singh Gurbachan, Bundela DS, Sethi M, Lal K, Kamra SK (2010) Remote Sensing and Geographic Information System for appraisal of salt-affected soils in India. Journal of Environmental Quality 39(1): 5-15.
6. Mandal AK, Sharma RC (2010) Computerized database of salt affected soils in Peninsular Indiausing Geographic Information System. Journal of the Indian Society of Soil Science 58(1): 105-116.

7. Sharma RC, Mandal AK, Singh Ranbir, Singh YP (2011) Characteristics and use potential of sodic and associated soils in CSSRI experimental farm, Lucknow, Uttar Pradesh. Journal of the Indian Society of Soil Science 59(4): 381-387.

8. Mandal AK, Sethi M, Yaduvanshi NPS, Yadav RK, Bundela DS, et al. (2013) Salt affected soils of Nain experimental farm: site characteristics, reclaimability and potential use. Technical Bulletin pp. 34.

9. Mandal AK, Singh Ranbir, Joshi PK, Sharma DK (2016) Mapping and characterization of salt affected soils for reclamation and management A case study from the Trans- Gangetic Plain of India. pp. 29.

10. Rao BRM, Ravisankar T, Dwivedi RS, Thamappa SS, Venkatratnam L, et al. (1995) Spectral behavior of salt affected soils. International Journal of Remote Sensing 16(12): 2125-2136.

11. Sharma RC, Mandal AK, Singh Ranbir (2011) Delineation \& characterization of waterlogged \& salt affected soils in Gandak command area of Bihar for reclamation and management.Journal of the Indian Society of Soil Science 59(4): 315-320

12. Mandal AK (2012) Delineation and characterization of salt affected soils and waterlogged areas in the Indo-Gangetic plain of Central Haryana (Dist Kurukshetra) for reclamation and management. Journal of Soil Salinity and Water Quality 4: 21-25.

13. Gupta SK (2010) Management of alkali water. Central Soil Salinity Research Institute, Karnal. India, Technical Bulletin 1: 1-71.

14. Singh Gurbachan, Mandal AK (2007) Advances in the assessment of salt affected soils for mapping \& monitoring in India \& management strategies. First Expert Consultation Advances in Assessment and Monitoring of salinization for Managing Salt affected Habitats FAO's Global Network on SPUSH pp: 45-61.

15. Mandal AK, Sharma RC (2011) Delineation and characterization of waterlogged salt affected soils in IGNP using remote sensing and GIS. Journal of the Indian Society of Remote Sensing 39: 39-50.

16. Mandal AK, Obi Reddy GP, Ravisankar T (2011) Digital database of salt affected soils in India using Geographic Information System. Journal of Soil Salinity and Water Quality 3:16-29.

17. Indo-Dutch Network Project (2002) A methodology for identification of water logging and soil salinity conditions using remote sensing. CSSRI Karnal and ALTERRA-ILRI Wageningen pp. 78.

18. Mandal AK (2016) Mapping and characterization of salt affected and waterlogged soils in the Gangetic plain of central Haryana (India) for reclamation and management. Cogent Geoscience.

19. Mandal AK, Sharma RC (2014) Delineation and characterization of waterlogged salt affected soils in Loonkaransar Area of IGNP for reclamation and management. Annals of Arid Zone 53(3\&4): 143-151.

20. Patil NG, Ray SK, Chandran P, Nagaraju MSS, Tiwari P (eds.) Sustainable Management of Land Resources for Livelihood Security.

21. Sharma RC, Mandal AK (2006) Mapping of soil salinity \& sodicity in irrigated lands of the Indo-Gangetic Plain using image analysis and GIS Agropedology 16: 71-76. 


\section{(6) (1) \\ This work is licensed under Creative \\ Commons Attribution 4.0 License}

To Submit Your Article Click Here: Submit Article

DOI: $10.32474 /$ CIACR.2018.02.000149

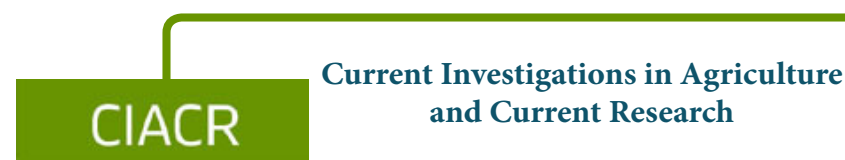

\section{Assets of Publishing with us}

- Global archiving of articles

- Immediate, unrestricted online access

- Rigorous Peer Review Process

- Authors Retain Copyrights

- Unique DOI for all articles 